\title{
Ecological and technological control over the washing and sanitizing means in milk branch
}

\author{
O. Zhukorskyi, \\ corresponding member of NAAS, doctor of agricultural sciences \\ National Academy of Agricultural Sciences of Ukraine \\ Ye. Kryvokhyzha, \\ candidate of veterinary sciences, Senior Researcher \\ Institute of Agroecology and Environmental Management NAAS
}

The purpose. To analyze the content of active matters in washing and sanitizing means and to evaluate levels of their receipt into environment after sanitization of milking equipment and cisterns of milk lorries. Methods. Calculation. Results. Under the developed formulas the level is determined of receipt into environment of spent solutions of some washing and sanitizing means which are used in milk branch. Conclusions. 142,4 tons of chemicals per year are spoiled into environment at use in private facilities, dairy-commercial farms with a livestock up to 10 thousand cows, and milk factories for cleaning 20 cisterns of milk lorries of the following washing means: Vimol, Origami Golden, Pur Power Lemon, Roko Agro A, Sidmax, Tesol ME and Zhavel-Kleid. That can negatively influence ecosystems.

Key words: washing-sanitizing means, sanitization, milking equipment, environment.

Problem. On farms an especially important value has maintenance of cleanness and observance of relevant sanitary norms and rules in relation to milking equipment [1, 2]. For the sanitary processing of milking equipment use of solutions of detergents, disinfectants and detergents disinfectants, that on chemical properties is divided into alkaline and acid [3]. At the same time plenty of these means contains active chlorine compounds, surface active agents and phosphates [4]. If released of these substances into body of water happens violation of natural biocenosis.

Analysis of recent researches and publications. Ecological questions that is related with the use of detergents and disinfectants covered in researches of such scientists as: E. Kolber [5], R. Perry [6], N. Feisthauer [7], M.J. Scott [8], M. Dettenkofer [9], C. Boillot [10] and others. However, the literature does not describe the method of control of the intake into the environment of waste solutions detergents and disinfectants in milk branch by calculation.

The purpose of research. Performing the analysis of the content of active substances in detergents and disinfectants available on the Ukraine market and level estimate of the intake into the environment after sanitary processing milking equipment and of mobile milk tanker trucks.

Material and methods of research. Determining the level of the intake into the environment chemical active substances waste solutions detergents disinfectants for milking equipment, milk containers and milk coolers at farms of different ownership forms and of mobile milk tanker trucks on dairy factories calculated proposed by our formulas.

$$
\mathrm{m}_{\mathrm{me}}=\mathrm{a} \times(\mathrm{k} \times \mathrm{d}) \times \mathrm{e} \times \mathrm{I}, \text { (active units) }
$$

where:

$\mathrm{m}_{\mathrm{me}}$ - the quantity of active substance of chemical waste detergent disinfectant is after sanitary processing of milking equipment on milking farm or private farms;

a - total number of cows, heads;

$\mathrm{k}$ - the average quantity of detergent disinfectant from the calculation of the use on one cow, active units;

$\mathrm{d}-$ the quantity of separate active substance of detergent disinfectant, \%;

$\mathrm{e}$ - the number of sanitary processings a day; 
I- duration of sanitary processings, days.

$$
k=\frac{f}{g}, \text { (active units) }
$$

where:

$\mathrm{k}$ - the average quantity of detergent disinfectant from the calculation of the use on one cow, active units;

$f$ - the quantity of working solution of detergent disinfectant for performance of one sanitary processing of milking equipment on milking farm or private farms according to instructions;

$\mathrm{g}$ - the quantity of cows in cowshed.

$$
\mathrm{m}_{\mathrm{cmtt}}=\mathrm{b} \times \frac{(\mathrm{c} \times \mathrm{d})}{100} \times \mathrm{e} \times \mathrm{I}, \text { (active units) }
$$

where:

$m_{\mathrm{cmtt}}$ the quantity of active substance of chemical waste detergent disinfectant after sanitary processing separate for milk coolers or mobile milk tanker trucks;

$\mathrm{b}$ - the quantity of milk coolers or mobile milk tanker trucks, pieces;

c - the quantity of working solution of detergent disinfectant for sanitary processing separate for one milk coolers or mobile milk tanker trucks, active units;

$\mathrm{d}$ - the quantity of separate active substance of detergent disinfectant, active units;

$\mathrm{e}-$ the number of sanitary processings of milk coolers or mobile milk tanker trucks

quanity or cooling tanks milk tankers per day;

I- duration of sanitary processings, days.

The main material. Processed instructions using available on the market separate of detergent and disinfectant for sanitary processing milking equipment and milk containers in the farms of different ownership forms and of mobile milk tanker trucks on dairy factories and analysed quantitative content they of active substances (table 1).

\begin{tabular}{|c|c|c|c|c|c|c|c|c|c|c|c|}
\hline \multirow[b]{3}{*}{ Product name } & \multirow[b]{3}{*}{$\begin{array}{l}\text { Producing } \\
\text { country }\end{array}$} & \multicolumn{10}{|c|}{ The quantitative content of components, $\%$} \\
\hline & & \multirow[b]{2}{*}{ 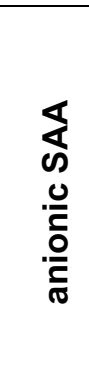 } & \multirow[b]{2}{*}{ 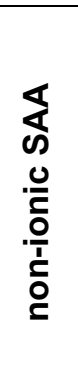 } & \multirow[b]{2}{*}{$\begin{array}{l}\frac{\pi}{4} \\
\text { क } \\
0 \\
\frac{0}{d} \\
\frac{0}{0} \\
\frac{c}{0} \\
\frac{0}{\sigma}\end{array}$} & \multirow[b]{2}{*}{$\begin{array}{l}\overline{\overline{\widetilde{T}}} \\
\frac{\overline{\bar{\sigma}}}{\bar{\sigma}}\end{array}$} & \multirow[b]{2}{*}{$\begin{array}{l}\text { 巳 } \\
\frac{\pi}{0} \\
\frac{0}{0} \\
\frac{0}{0} \\
\frac{0}{2}\end{array}$} & \multirow[b]{2}{*}{ 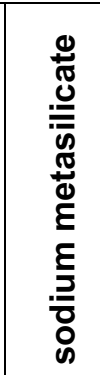 } & \multirow[b]{2}{*}{ 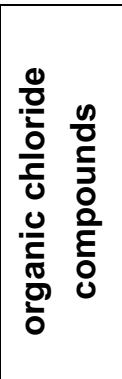 } & \multirow[b]{2}{*}{ 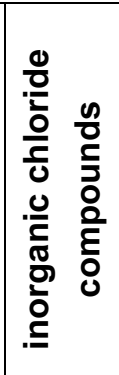 } & \multicolumn{2}{|c|}{ acids } \\
\hline & & & & & & & & & & $\begin{array}{l}\frac{0}{0} \\
\frac{0}{0} \\
\frac{0}{0} \\
\frac{0}{2} \\
\frac{0}{2}\end{array}$ & $\frac{0}{\frac{0}{2}}$ \\
\hline \multicolumn{12}{|c|}{ Private farms (milk pails and glass jars) } \\
\hline Vymol & Ukraine & - & 3,5 & - & - & 15,0 & 10,0 & - & - & - & - \\
\hline Origami Golden & Ukraine & 15,0 & 5,0 & 5,0 & - & - & - & - & - & - & - \\
\hline Pur Power Lemon & Poland & 15,0 & - & 5,0 & - & - & - & - & - & - & - \\
\hline \multicolumn{12}{|c|}{ Dairy farms (milking equipment) } \\
\hline Roko Agro A & Poland & - & - & - & 15,0 & - & - & - & 25,0 & - & - \\
\hline Sidmaks & Sweden & - & - & - & - & - & - & - & - & 20,0 & 10,0 \\
\hline \multicolumn{12}{|c|}{ Dairy factories (mobile milk tanker trucks) } \\
\hline Tesol ME & Poland & - & - & - & 15,0 & - & - & - & 9,2 & - & - \\
\hline Javel-kleid & France & - & - & - & 10,0 & - & - & 82,0 & - & - & - \\
\hline
\end{tabular}

1. The content of active substances of detergent and disinfectant in milk branch

On the market of Ukraine in the vast majority are available imported product, which is 2.5 times more compared to domestic. In detergents that use in the private farms part of content of SAA will be $66.0 \%$, phosphates $-20.4 \%$ and sodium metasilicate $-13.6 \%$. In the detergent and disinfectant for milking equipment on dairy farms part of 
alkali and organic chloride compounds $-57.1 \%$ and acids $-42.9 \%$. In the means for mobile milk tanker trucks part of organic and inorganic chloride compounds constitutes $-78.5 \%$ and alkali $-21.5 \%$.

We have determined the level of intake into the environment of waste solutions of certain detergents and disinfectants during the year after of realization sanitary processing milk containers in the private farms and milking equipment on dairy farms with an amount for 10,000 cows. And also after realization of sanitary processing 20 milk tanker trucks on dairy factories we have proposed formulas (figure 1).

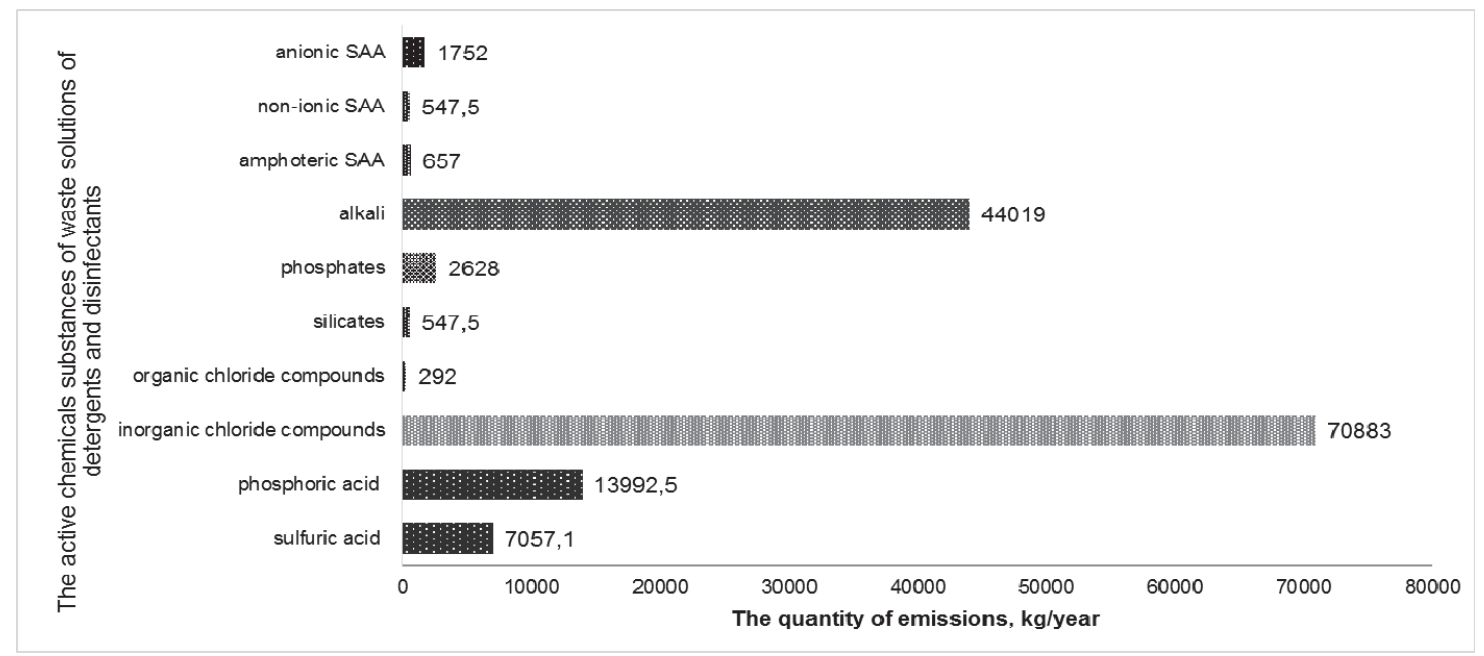

Figure 1. The intake of active substances of detergents and disinfectants into the environment after realization of sanitary processing of milking equipment and mobile milk tanker trucks

When using in private farms of such means, as Vymol, Origami Golden, Pur Power Lemon. On dairy farms: Roko Agro A and Sidmaks, and also of dairy factories for sanitary processing milk tanker trucks: Tesol ME and Javel-kleid most of all into the environment coming inorganic chloride compounds, alkalis and acids, which accounted for $49.8 \%, 30.9 \%$ and $14.8 \%$ respectively. To a lesser degree are output SAA, phosphates silicates and organic chloride compounds, which amounts $2.1 \%, 1.8 \%, 0.4 \%$ and $0.2 \%$ respectively. Releases into the environment of the chemical active substances of these means after their use during the year in a total amount of 142.4 tonnes/year can have a negative impact on ecosystems.

After sanitary processing milk containers in the private farms waste solutions of detergent preferably poured directly into the environment. On dairy farms waste solutions of detergents and disinfectants poured into the local sewage installations from which they released into cedimentation tanks. Cedimentation tanks on dairy farms during filling them urine and waste solutions of detergents and disinfectants may have a negative impact on soil ecosystems due of flowing the contents with storm water and melted waters, why erosion of soils especially promotes. Waste solutions of detergents and disinfectants after sanitary processing milk tanker trucks poured down into sewage installations from which they subsequently are entering into the environment.

Consequently, wastewater of private farms, dairy farms and dairy factories contain numerous contaminants in particular, phosphates, nitrates, chlorides, sulfates, surface active agents that can negatively influence on the state of ecosystems.

Conclusions

We have developed formulas, which allow us to determine the level of intake chemical active substances waste detergents and disinfectants into the environment after sanitary processing milking equipment in the farms of different ownership forms and of mobile milk tanker trucks on dairy factories.

When using in private farms, milking farm for 10,000 cows, and dairy factories for sanitary processing 20 milk tanker trucks means: Vymol, Origami Golden, Pur Power Lemon, Roko Agro A, Sidmaks, Tesol ME and Javel-kleid in environment during the year came 142,4 tons/year of chemicals that can cause negative effects on ecosystems.

Prospects of subsequent researches. Further the identification and control hazardous detergents and disinfectants in milk branch will reduce the negative influence on the ecosystem. 


\section{Bibliography}

1. Fagan E.P., Betoli V., Barros M.A.F. (2005). Evaluation and implementation of good pratices in main points of microbiological contamination in milk production. Semina : Ciências Agrárias, 26 (1):83-92.

2. Jones G.M. (2009). Cleaning and Sanitizing Milking Equipment. Publications (Virginia Cooperative Extension), 400-404:1-4. Available at: https://pubs.ext.vt.edu/404/404-400/404-400.html.

3. Reinemann D.J., Wolters G., Billon P., Lind O. Rasmussen M.D. (2009). Review of practices for cleaning and sanitation of milking machines. Bulletin-International Dairy Federation, 381:4-19.

4. Zhukors'kyy, O.M., Kryvokhyzha Ye.M. (2016). Otsinyuvannya rivnya nadkhodzhennya vidprats'ovanykh rozchyniv myyno-dezinfikuyuchykh zasobiv dlya doyil'noho ustatkuvannya na fermakh u dovkillya [Evaluation of the level of ingress of used solutions detergents disinfectants means for milking and diary equipment on a farm in the natural environment]. Naukovo-tekhnichnyy byuleten' IT NAAN [Scientific and technical bulletin of Institute of Animal of NAAS], 115:75-82 [in Ukrainian].

5. Kolber E. (1990). Detergents, the Consumer and the Environment. Chemistry \& Industry, 6:179-181.

6. Perry R., Kirk P.W.W., Stephenson T., Lester J.N. (1984). Environmental Aspects of the use of NTA as a Detergent Builder. Water Research, 18 (3):255-276.

7. Feisthauer N., Sibley P., Burke S. Kaushik N. (2004). A review of the toxicity of detergents and its formulation components on aquatic organisms. International Journal of Ecology and Environmental Science, 28:223-297.

8. Scott M.J., Jones, M.N. (2000). The biodegradation of surfactants in the environment. Biochimica et Biophysica Acta, 1508:235-251.

9. Dettenkofer M., Spencer R.C. (2007). Importance of environmental decontamination - a critical view. Journal of Hospital Infection, 65 (2):55-57.

10. Boillot C., Perrodin Y. (2008). Joint-action ecotoxicity of binary mixtures of glutaraldehyde and surfactants used in hospitals: Use of the Toxicity Index model and isoblogram representation. Ecotoxicology and Environmental Safety, 71 (1):252-259. 